\title{
Effects of different sowing time to phenology and yield of winter wheat
}

\author{
Martynas Klepeckas ${ }^{1}$, Irena Januškaitienè $\dot{1}^{1}$, llona Vagusevičiené2 ${ }^{2}$ and Romualdas Juknys ${ }^{1}$ \\ ${ }^{1}$ Vytautas Magnus University, Faculty of Natural sciences, Universiteto street 10, LT-53361, Akademija, Lithuania \\ ${ }^{2}$ Vytautas Magnus University, Faculty of Agronomy, Studentu street 11, LT-53361, Lithuania \\ e-mail: martynas.klepeckas@vdu.It
}

\begin{abstract}
This study aims to determine optimal sowing date for winter wheat (Triticum aestivum L.) and invoke DSSAT Nwheat model to analyze impact of modified sowing date to phenological development and grain yield. Wheat was grown for three seasons in two locations across Lithuania and sowing was carried out one time per week from 1 September to 29 September. Average three-year temperature of vegetation period gets lower every week by $0.16^{\circ} \mathrm{C}$, and available GDD by $94.5^{\circ} \mathrm{C}$ when sowing time is delayed. Modeling results showed that tillering rate is affected by sowing time winter wheat grew 232 (tillers $\mathrm{m}^{-2}$ ) less with each week of delayed sowing. Grain filling stage was shortened by 1.25 days with each delayed sowing week. Depending on sowing time yield varied from $8.58 \mathrm{t} \mathrm{ha}^{-1}$ to $6 \mathrm{t}$ $\mathrm{ha}^{-1}$ while simulated harvest was $8 \%$ lower. We conclude that best winter wheat sowing time for current climatic conditions in Lithuania is mid-September and DSSAT model proves as a useful tool in anticipating sowing time while facing problems caused by a climate change.
\end{abstract}

Key words: Triticum aestivum, development, harvest, modeling

\section{Introduction}

Climate change causes increasing concern for our society by putting crops and food safety at risk. Worldwide wheat production exceeds other cereals production because wheat is one of the key crops in making main food products like flour, bread, and pasta. It is also used as the main ingredient for animal feed while replacing corn. From 1961 to 2018 global wheat production has been increasing every year at $0.9 \%$ rate (Cauvain 2012, www.fao.org). Every year millions of tons of cereals are lost due to climate change induced excessive rainfall, too high temperatures in summer or too low temperatures during winter for winter cultivars. Moreover, it has been proven that plant phenology shifts due to changing warm and cold time periods over the year (Wittich and Liedtke 2015). In the period from 1971 to $2000,78 \%$ of all crop phenology records analyzed by Menzel et al. (2006) in 21 European countries have shown significant changes in phenological occurrences.

However, as plant phenology is affected by the climate, agronomic practices and by altering cultivars, the response of cereals is more complicated than wild crops (Liu et al. 2018a). For example, wheat has multiple sowing dates across the year in Europe. Farmers tend to sow winter wheat in mid-fall and harvest them in upcoming mid-summer, or sow spring wheat in early spring and harvest them in late summer. Cereals like winter wheat grew in Finland by about 10 days more in the growing season due to a crop cultivar change (Hilden et al. 2005). It has been noticed that phenological growth stages duration is dependent on the crop management and shifting sowing-date highly impacts crops (Hu et al. 2017, Liu et al. 2018b).

Wang et al. (2013) and He et al. (2015) recorded that climate variables such as temperature and precipitation can significantly impact wheat harvest. The rise in temperature could also accelerate the growth of crops, while a longer growing cultivars or late sowing date could lead to delayed growth. Warming alone caused similar rates of yield declines in sites and crop varieties under baseline precipitation (5-7 percent at $1^{\circ} \mathrm{C}$ ) (Pirttioja et al. 2015).

To try to anticipate and prevent such problems in future crop simulation models are developed. The interactions between environmental changes, crop management procedures and cultivar change could not be captured by simple statistical models. But process-based crop models can simulate crop interactions, environmental factors, and management processes dynamically (Pirttioja et al. 2015).

One of the most popular crop models is DSSAT (Decision Support System for Agrotechnology Transfer) created by Jones et al. (2003) and Hoogenboom et al. (2019) and used by many researchers around the world (Feng et al. 2015, Yao et al. 2015, Attia et al. 2016, Adhikari et al. 2017, Tang et al. 2018). The DSSAT model simulates crop growth, phenological crop development and crop yield on a uniform area of land under completed or simulated management. 


\section{AGRICULTURAL AND FOOD SCIENCE}

M. Klepeckas et al. (2020) 29: 346-358

Soil water, carbon and nitrogen balance changes are also simulated in this crop model over time (Porter et al. 2000, Jones et al. 2003, Hoogenboom et al. 2019).

This study aims to evaluate winter wheat phenological development and yield gain at different sowing dates and utilizing DSSAT (4.7) Nwheat model to determine the best sowing time to achieve optimal winter wheat phenological parameters and yield based on observed data of field experiments in Lithuania.

\section{Material and methods \\ Experiment locations}

Field experiments were carried for three years (2016-2019) at two distant sites across Lithuania (Fig. 1). Experiments were conducted at Vytautas Magnus University faculty of Natural Sciences and Agriculture Academy. Both study sites are located in middle Lithuanian lowland, first study site 'Biržai' ( $56^{\circ} 6^{\prime} \mathrm{N}, 24^{\circ} 46^{\prime}$ ' E) and second 'Kaunas' $\left(54^{\circ} 53^{\prime} \mathrm{N}, 23^{\circ} 50^{\prime} \mathrm{E}\right)$ were $200 \mathrm{~km}$ apart from each other.

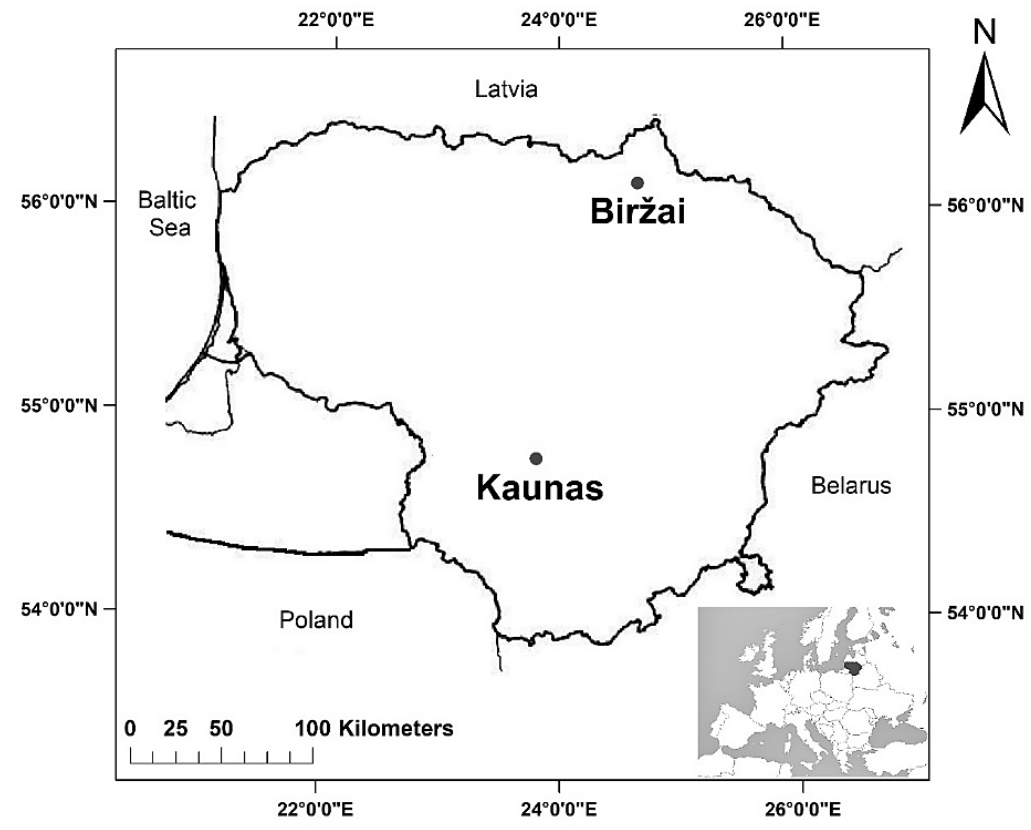

Fig. 1. Location of experimental sites in Lithuania

\section{Weather data}

Lithuanian climate is classified as humid continental climate with clearly defined four seasons. The average annual temperature and precipitation of Lithuania are $18{ }^{\circ} \mathrm{C}$ and $656 \mathrm{~mm}$, respectively. Winter period weather in Lithuania is generally cold with frequent powerful frosts. Mean winter temperature is $-2.9{ }^{\circ} \mathrm{C}$. At both Kaunas and Biržai sites, the average snow-covered days from 85 to 94 days respectively, multi-year mean maximum snow depth varies 14 to $18 \mathrm{~cm}$ respectively. In winter average precipitation amount reaches $134 \mathrm{~mm}$. Summer season weather is distinguished as humid and hot with mean temperature and precipitation $16.3^{\circ} \mathrm{C}$ and $220 \mathrm{~mm}$ respectively. The total annual solar radiation mean in Lithuania is assessed at $3600 \mathrm{MJ} \mathrm{m}^{-2}$ (Bukantis 2001, Bukantis and Rimkus 2005, Rimkus et al. 2007, 2014).

Weather data was collected from the nearest weather stations of the Ministry of Environment of Lithuania. (www. meteo.lt).

The average temperature and thermal time of the observed vegetation period for all sowing dates showed significant differences between both locations and sowing dates during all three years (Table 1). When wheat was sown in one-week intervals, vegetation period temperature tended to decrease on average $0.19{ }^{\circ} \mathrm{C}$ in Biržai $(r=0.99$, $p<0.05)$ and $0.14{ }^{\circ} \mathrm{C}$ in Kaunas $(r=0.99, p<0.05)$ with each week. 


\section{AGRICULTURAL AND FOOD SCIENCE}

M. Klepeckas et al. (2020) 29: 346-358

Table 1. Observed mean vegetation period (sowing to maturity) temperature $\left({ }^{\circ} \mathrm{C}\right)$, precipitation $(\mathrm{mm})$ and thermal time (growing degree days, ${ }^{\circ} \mathrm{C}$ ) at different sowing dates for three growing seasons, shown together with a confidence level $(p)$, coefficient of determination $\left(\mathrm{R}^{2}\right)$ and standard deviation (SD) when one season values are compared to two other seasons.

\begin{tabular}{|c|c|c|c|c|c|c|c|c|c|c|}
\hline \multirow{2}{*}{\multicolumn{2}{|c|}{$\begin{array}{l}\text { Sowing date } \\
\text { Season }\end{array}$}} & \multicolumn{3}{|c|}{ temperature $\left({ }^{\circ} \mathrm{C}\right)$} & \multicolumn{3}{|c|}{ precipitation (mm) } & \multicolumn{3}{|c|}{ thermal time $\left(\mathrm{GDD},{ }^{\circ} \mathrm{C}\right)$} \\
\hline & & $2016-2017$ & $2017-2018$ & 2018-2019 & $2016-2017$ & $2017-2018$ & $2018-2019$ & $2016-2017$ & $2017-2018$ & 2018-2019 \\
\hline \multirow[t]{9}{*}{ Biržai } & 1 September & 6.2 & 7.5 & 6.9 & 604.6 & 701.5 & 612.1 & 2401.5 & 2537.7 & 2469.6 \\
\hline & 8 September & 6.1 & 7.4 & 6.7 & 603.2 & 697.1 & 589.2 & 2291.2 & 2446.4 & 2368.8 \\
\hline & 15 September & 5.8 & 7.2 & 6.5 & 603.2 & 671.8 & 576.5 & 2178.3 & 2340.5 & 2259.4 \\
\hline & 22 September & 5.6 & 7.0 & 6.3 & 603.0 & 606.7 & 543.9 & 2098.8 & 2254.8 & 2176.8 \\
\hline & 29 September & 5.4 & 6.7 & 6.2 & 598.4 & 601.8 & 539.1 & 2027.2 & 2156.2 & 2091.7 \\
\hline & Index & & & & & & & & & \\
\hline & $p^{\text {a }}$ & $<0.05$ & $<0.05$ & $<0.05$ & $>0.05$ & $<0.05$ & $>0.05$ & $<0.05$ & $<0.05$ & $<0.05$ \\
\hline & $R^{2 b}$ & 0.97 & 0.94 & 0.94 & 0.54 & 0.81 & 0.81 & 0.99 & 0.99 & 0.99 \\
\hline & $S D^{c}$ & 0.33 & 0.32 & 0.28 & 2.36 & 48.41 & 30.81 & 149.57 & 150.9 & 150.1 \\
\hline \multirow[t]{9}{*}{ Kaunas } & 1 September & 6.8 & 8.1 & 7.5 & 603.9 & 741.4 & 651.7 & 2649.8 & 2914.1 & 2781.9 \\
\hline & 8 September & 6.7 & 8.0 & 7.4 & 589.2 & 716.3 & 631.8 & 2526.5 & 2719.9 & 2623.2 \\
\hline & 15 September & 6.4 & 7.9 & 7.2 & 589.2 & 704.9 & 626.1 & 2442.7 & 2531.9 & 2487.3 \\
\hline & 22 September & 6.3 & 7.8 & 7.1 & 589.0 & 654.7 & 600.9 & 2371.7 & 2234.2 & 2303.0 \\
\hline & 29 September & 6.1 & 7.7 & 6.9 & 583.7 & 654.3 & 598.0 & 2005.2 & 2122.6 & 2063.9 \\
\hline & Index & & & & & & & & & \\
\hline & $p^{a}$ & $<0.05$ & $<0.05$ & $<0.05$ & $>0.05$ & $<0.05$ & $>0.05$ & $<0.05$ & $<0.05$ & $<0.05$ \\
\hline & $R^{2 b}$ & 0.98 & 0.98 & 0.98 & 0.64 & 0.89 & 0.89 & 0.85 & 0.95 & 0.95 \\
\hline & $S D^{c}$ & 0.28 & 0.15 & 0.23 & 7.58 & 38.67 & 22.44 & 243.3 & 329.3 & 279.3 \\
\hline
\end{tabular}

${ }^{a}$ confidence level; ${ }^{b}$ coefficient of determination for the 1 to 2 line; ${ }^{c}$ standard deviation

\section{Soil data}

Soil was analyzed at Lithuanian Research Center for Agriculture and Forestry laboratory. Soil at experimental sites was analyzed before sowing up to $140 \mathrm{~cm}$ depth. Both sites have an average surface soil texture $(0-30 \mathrm{~cm}) \mathrm{com}-$ posed of $40 \%$ sand, $44 \%$ silt and $15 \%$ clay. The soil was neutral $(\mathrm{pH}=7.4)$, high in potassium $\left(116 \mathrm{mg} \mathrm{kg}^{-1} \mathrm{~K}_{2} \mathrm{O}\right)$ and phosphorus ( $230 \mathrm{mg} \mathrm{kg}^{-1} \mathrm{P}_{2} \mathrm{O}_{5}$ ), contained about $1.54 \%$ of organic carbon, $2.22 \%$ of humus and $0.12 \%$ of total nitrogen at Kaunas experimental site (Table 2). In Biržai soil was slightly denser, and higher levels of nitrogen (0.324\%), hummus (3.13\%), organic carbon (1.78\%), phosphorous (310 mg kg-1 $\mathrm{P}_{2} \mathrm{O}_{5}$ ) and potassium $\left(195 \mathrm{mg} \mathrm{kg}^{-1} \mathrm{~K}_{2} \mathrm{O}\right)$ was found.

Table 2. Soil chemical and physical properties at experimental sites

\begin{tabular}{|c|c|c|c|c|c|c|c|c|}
\hline Site location & Soil layer & $\begin{array}{l}\text { Density, } \\
\mathrm{g} \mathrm{cm}^{-3}\end{array}$ & $\mathrm{pH}$ & $\begin{array}{c}\text { Total nitrogen, } \\
\mathrm{mg} \mathrm{kg}^{-1}\end{array}$ & $\begin{array}{l}\text { Humus, } \\
\text { mg kg }^{-1}\end{array}$ & $\begin{array}{c}\text { Organic carbon, } \\
\mathrm{mg} \mathrm{kg}^{-1}\end{array}$ & $\begin{array}{l}\text { Phosphorous, } \\
\mathrm{mg} \mathrm{kg}^{-1}\end{array}$ & $\begin{array}{l}\text { Potassium, } \\
\mathrm{mg} \mathrm{kg}^{-1}\end{array}$ \\
\hline \multirow[t]{2}{*}{ Kaunas } & $0-30 \mathrm{~cm}$ & 1.43 & 7.4 & 1260 & 22200 & 15400 & 230 (high) & 116 (high) \\
\hline & $60-100 \mathrm{~cm}$ & 1.61 & 7.4 & 790 & 5200 & & & \\
\hline \multirow{3}{*}{ Biržai } & $30-60 \mathrm{~cm}$ & 1.61 & 7.5 & 2190 & 5400 & & & \\
\hline & $60-100 \mathrm{~cm}$ & 1.67 & 7.4 & 1310 & 6000 & & & \\
\hline & $100-140 \mathrm{~cm}$ & 1.72 & 7.4 & 200 & 4400 & & & \\
\hline
\end{tabular}




\section{AGRICULTURAL AND FOOD SCIENCE}

M. Klepeckas et al. (2020) 29: 346-358

\section{Management practices}

For this experiment winter wheat cultivar 'Skagen' was selected. It has notable winter hardiness and relatively high productivity compared to other cultivars which made it popular among farmers not only in Lithuania but across Europe (Ruzgas et al. 2017, Feledyn-Szewczyk et al. 2018).

Precursor crop was winter rape. For this experiment wheat seeds were sown at a different time - at 1-week interval, starting from 1 September to 29 September. Sowing was carried out on five dates at 1, 8, 15, 22, and 29 September. Seeds were sown in soil at $200 \mathrm{~kg} \mathrm{ha}^{-1}$ amount ( 450 seeds $\mathrm{m}^{-2}$ ) in $3.5 \mathrm{~cm}$ depth, $13 \mathrm{~cm}$ row spacing. Also, during experiment wheat was fertilized with ammonium nitrate $\left(200 \mathrm{~kg} \mathrm{ha}^{-1}\right)$ at growth stages BBCH 21 and BBCH 30. Measurements were taken every 7 days during all growing seasons from emergence until maturity.

\section{DSSAT-Nwheat model}

The Decision Support System for Agrotechnology Transfer (DSSAT) is a crop modelling software that includes crop simulation models for over 42 plant species. For this study DSSAT 4.7 version of NWheat model was selected. To create DSSAT-Nwheat model, APSIM-Nwheat model was taken and it was incorporated into the DSSAT (v4.7) platform. NWheat has been validated worldwide for temperature, water, nitrogen management and $\mathrm{CO} 2$ concentration parameters with controlled field studies in a variety of settings and agronomic treatments with different environments (Kassie et al. 2016). NWheat has recently been modified by an $\mathrm{O}_{3}$ effect sub-routine, which represents a photosynthesis decrease and accelerated $\mathrm{O}_{3}$ stress of leaf senescence (Guarin et al. 2019).

DSSAT model requires data input describing daily meteorological conditions, cultivar growth and development properties, management activities and soil features. Daily precipitation, temperature ( $\min$ and $\max$ ), solar radiation, and description of the weather stations (longitude and latitude) are the minimum weather data requirements. The main inputs to soil data include the original soil content of water, upper and lower drainage limits, water saturation, runoff or drainage, root growth conditions, soil albedo and evaporation. The crop management data input for modeling contains of sowing dates and depths, population density of plants and fertilizer and irrigation application dates and measured or calculated original soil water and nitrogen content.

DSSAT-Nwheat is based on CERES-wheat with the same data input but it also needs to be calibrated with more cultivar coefficients. The models use various cultivar genetic coefficients such as vernalization requirement (P1V), Photoperiod sensitivity (P1D), Thermal time requirement (P5), Kernel number per biomass (G1), Kernel growth rate (G2), Maximum stem dry weight (G3), Interval between leaf appearance (PHINT). Every acquired coefficient is different with distinct circumstances (weather, fertilizer etc.). Also, for model output evaluation experimental data is necessary. The GenCalc program, especially intended for calibration of crop cultivars, (along with other author research shown in Table 3) has been used in the DSSAT Package for cultivar coefficient calibration (Hunt et al. 1993, Liu et al. 2017). In the calibration process a "trial and error" method was used to compare the best agreement for parameter calibration, i.e. root mean square error (RMSE) was used to estimate the minimal differences between the simulated and the observed yield by adjusting plant genetic coefficients. Model results were validated using data from side experiment (using same conditions and methods) where different amounts of fertilizer were added. Model validation was conducted by comparing the observed against simulated yield data, maturity date and leaf area index and evaluating their RMSE, D-index and standard deviation values.

\section{Statistical analysis}

For the comparison of simulated data with observed values $R^{2}$ (coefficient of determination), $r$ (correlation coefficient), RMSE (Root mean square error) (1), and agreement index (D-index) (2) statistics were used suggested by Phakamas et al. (2013). The RMSE was used to compare the accuracy and the gap between the observed field experiment results $\left(\mathrm{x}_{\mathrm{o}}\right)$ and the simulated results $\left(\mathrm{x}_{\mathrm{e}}\right)$ from the crop simulation model:

$$
R M S E=\sqrt{\frac{\sum_{i=1}^{N}\left(t_{e}-t_{o}\right)^{2}}{N}}
$$

In calculating the concordance between the observed and the simulated data the $D$ stat ( $D$ index), a descriptive measure (both relative and bounded) was used:

$\mathrm{D}-$ index $=1-\left[\frac{\sum_{i=1}^{N}\left(x_{e}-x_{o}\right)^{2}}{\sum_{i=1}^{N}\left[\left|x_{e}^{\prime}\right|+\left|x_{o}^{\prime}\right|\right]^{2}}\right]$

Where $\mathrm{N}$ is the number of observations, $\left(\mathrm{x}_{\mathrm{e}}\right)$ is calculated value of measurement and $\left(\mathrm{x}_{\mathrm{o}}\right)$ is observed value of measurement. When $\mathrm{D}$ stat is closest to 1 , model works the best. 
Table 3. Winter wheat genetic coefficients according to other studies

\begin{tabular}{|c|c|c|c|c|c|c|c|c|c|c|}
\hline \multirow[t]{2}{*}{ Species/cultivar } & \multirow[t]{2}{*}{ Location } & \multirow[t]{2}{*}{ Climate } & \multicolumn{7}{|c|}{ Coefficients } & \multirow[t]{2}{*}{ Source } \\
\hline & & & P1V & P1D & P5 & G1 & G2 & G3 & PHINT & \\
\hline Hereward (Ta) & UK & Temperate oceanic & 60 & 75 & 500 & 30 & 40 & 1.5 & 95 & Cho et al. 2012 \\
\hline$w W w^{*}$ & USA (Texas) & Subtropical & 10 & 68 & - & 30 & 30 & 1 & 30 & Adhikari et al. 2017 \\
\hline Ww* & USA (Texas) & Semi-arid & 45 & 80 & 700 & 25 & 32 & 2.8 & 100 & Attia et al. 2016 \\
\hline $\mathrm{Ww}(\mathrm{Td}) * *$ & Italy & Mediterranean & 30 & 55 & 450 & 25 & 55 & 1.7 & 100 & Dettori et al. 2011 \\
\hline Capo (Ta) & Austria & Semi-humid continental & 60 & 90 & 560 & 28 & 42 & 1.33 & 95 & Thaler et al. 2012 \\
\hline Bainong 207 (Ta) & China & Temperate continental & 64 & 80 & 696 & 30.2 & 45 & 1.5 & 90 & Tang et al. 2018 \\
\hline$W_{w}^{* *}$ & China & Moderate continental & 39.9 & 87.4 & 635 & - & - & - & 100 & Feng et al. 2015 \\
\hline $\mathrm{Ww} * *$ & China & Semi-humid & 25 & 52 & 515 & 47 & 40 & 2 & 105 & Li et al. 2015 \\
\hline $\mathrm{Ww}^{* *}$ & China & Arid & 52.9 & 90 & 595.7 & 27.5 & 39.2 & 1.7 & 96.4 & Yao et al. 2015 \\
\hline
\end{tabular}

Wv = winter wheat; Td = Triticum Durum; Ta = Triticum aestivum; ${ }^{*}$ Cultivar not specified; **Multiple cultivars used; P1V = Days of optimum vernalizing temperature required for vernalization (d); P1D= Photoperiod response (\% reduction in rate/10 h drop in pp); P5 = Grain filling phase duration $\left({ }^{\circ} \mathrm{C} . \mathrm{d}\right)$; $\mathrm{G} 1=$ Kernel number per unit canopy weight at anthesis (\#/g); G2 = Standard kernel size under optimum conditions $(\mathrm{mg}) ; \mathrm{G} 3$ = Standard, non-stressed mature tiller weight ( $\mathrm{g} \mathrm{dwt}) ;$ PHINT = Interval between successive leaf tip appearances ( $\left.{ }^{\circ} \mathrm{C} . \mathrm{d}\right)$

\section{Results}

One of the objectives of this study was to calibrate the DSSAT model for climatic conditions of Lithuania and to determine cultivar genetic coefficients based on observed data. Model calibration was performed using observed data from 2016-2017, 2017-2018 and 2018-2019 seasons. Seven values for genetic coefficients were obtained by fitting model with the data from field experiments. Calibrated values are presented in Table 4 along with default values used in DSSAT model.

\begin{tabular}{lcc}
\multicolumn{3}{l}{ Table 4. Genetic coefficients fitted for the cultivar Skagen } \\
\hline Parameter & Default value & Calibrated value \\
\hline P1V & 50 & 46.51 \\
P1D & 50 & 63.82 \\
P5 & 500 & 894.6 \\
G1 & 27 & 24.8 \\
G2 & 48 & 35.46 \\
G3 & 1.4 & 1.63 \\
PHINT & 95 & 95
\end{tabular}

$\mathrm{P} 1 \mathrm{~V}=$ Days of optimum vernalizing temperature required for vernalization (d); P1D = Photoperiod response (\% reduction in rate/10 h drop in $\mathrm{pp})$; $\mathrm{P} 5=$ Grain filling phase duration $\left({ }^{\circ} \mathrm{C} . \mathrm{d}\right) ; \mathrm{G} 1=$ Kernel number per unit canopy weight at anthesis (\#/g); G2 = Standard kernel size under optimum conditions (mg); G3 = Standard, non-stressed mature tiller weight (g dwt); PHINT = Interval between successive leaf tip appearances $\left({ }^{\circ} \mathrm{C} . \mathrm{d}\right)$

The calibration of the parameters was conducted to improve the model performance by adjusting the coefficients for a low RMSE and high d-index (Table 5). Model calibration for main phenological stages was more accurate for Biržai where RMSE for anthesis was 1.9 days and for maturity 2.41 days together with D-index -0.98 . 


\section{AGRICULTURAL AND FOOD SCIENCE}

M. Klepeckas et al. (2020) 29: 346-358

In Kaunas error was larger and reached 6.46 days for maturity date and 5.8 days for anthesis. On the contrary, for maximum leaf area index model calculations were more accurate in Kaunas, where RMSE was 0.69 while in Biržai it was twice as big - 1.51, and D-index - 0.81. Yield data calibration showed that RMSE was 0.144 and 0.427 t ha ${ }^{-1}$ in Biržai and Kaunas, respectively.

Table 5. DSSAT model calibration output with simulated and observed mean values, RMSE, $d$-index of major phenological variables (date of anthesis and physiological maturity (days)), yield $\left(\mathrm{t} \mathrm{ha}^{-1}\right)$ and maximum index of the leaf area (LAIX)

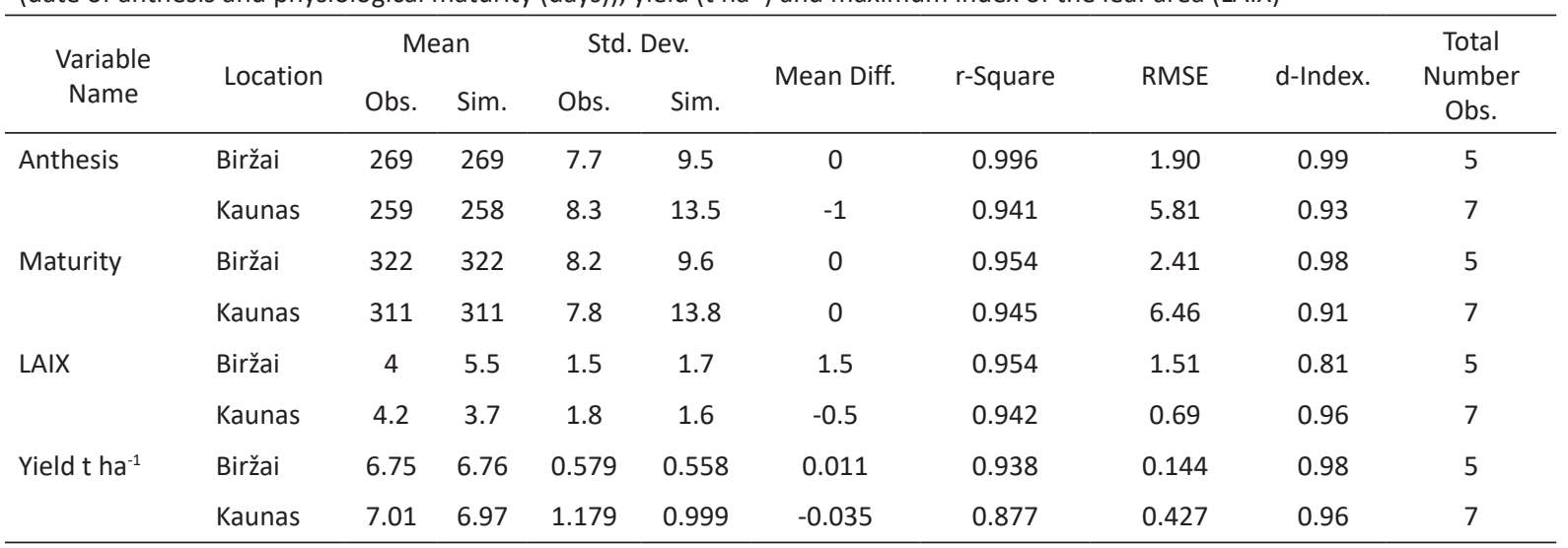

Regression analysis of simulated and observed values for model calibration can be seen in Figure 2. Relationship between observed and simulated data in Biržai was ( $r=0.99)$ for anthesis and $(r=0.97)$ maturity $(p<0.05)$, in Kaunas relationship was $(r=0.97$ and $r=0.97)$ respectively $(p<0.05)$. Lowest, relationship was found for yield in Kaunas $(r=0.93, p<0.05)$. The regression of simulated vs. observed leaf area index indicated a good agreement with $r$ of 0.97 in Biržai and Kaunas ( $r=0.96)$.

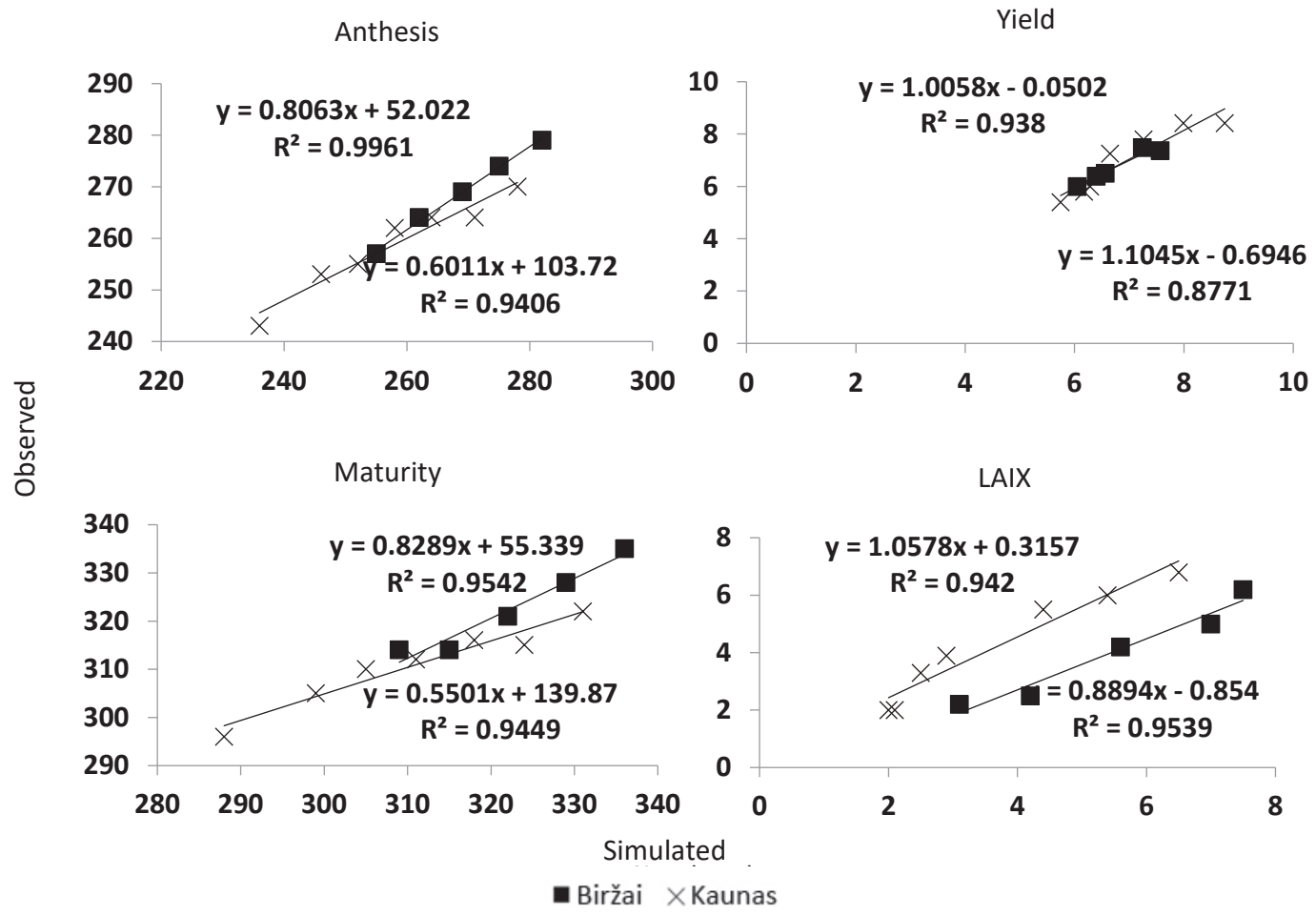

Fig. 2. Calibration curves for winter wheat anthesis, maturity (days after sowing), grain yield ( $t \mathrm{ha}^{-1}$ ) and $\mathrm{LAIX}$ (maximum leaf area index) plotted as observed vs simulated values.

Results reported in Table 6 show that for all three parameters, validation values used to test simulation accuracy between measured and simulated winter wheat data in different treatments achieved good simulation accuracy. RMSE value was 1.04, 0.013, and 0.15 for maturity date, leaf area index, and yield, respectively. D-index for all three parameters was higher than 0.97 , together with a coefficient of determination $0.96,0.98$ and 0.94 , respectively. 


\section{AGRICULTURAL AND FOOD SCIENCE}

M. Klepeckas et al. (2020) 29: 346-358

Table 6. Model validation results for winter wheat maturity date (DOY), leaf area index, and yield data $\left(\mathrm{t} \mathrm{ha} \mathrm{a}^{-1}\right.$ ) together with evaluated statistical parameters - RMSE, D-index, coefficient of determination, and standard deviation

\begin{tabular}{|c|c|c|c|c|c|c|}
\hline \multirow[b]{2}{*}{ Treatment } & \multicolumn{2}{|c|}{ Maturity date (DOY) } & \multicolumn{2}{|c|}{ Leaf area index } & \multicolumn{2}{|c|}{ Yield t ha-1 } \\
\hline & Observed & Simulated & Observed & Simulated & Observed & Simulated \\
\hline a & 311 & 310 & 2.53 & 2.5 & 6.46 & 6.46 \\
\hline b & 313 & 312 & 2.67 & 2.65 & 6.76 & 6.7 \\
\hline c & 312 & 312 & 3.31 & 3.31 & 7.01 & 6.99 \\
\hline$d$ & 313 & 311 & 3.36 & 3.36 & 7.12 & 7.14 \\
\hline RMSE & \multicolumn{2}{|c|}{1.04} & \multicolumn{2}{|c|}{0.013} & \multicolumn{2}{|c|}{0.15} \\
\hline d-index & \multicolumn{2}{|c|}{0.98} & \multicolumn{2}{|c|}{0.99} & \multicolumn{2}{|c|}{0.98} \\
\hline $\mathrm{R}^{2}$ & \multicolumn{2}{|c|}{0.96} & \multicolumn{2}{|c|}{0.98} & \multicolumn{2}{|c|}{0.94} \\
\hline SD & \multicolumn{2}{|c|}{0.96} & \multicolumn{2}{|c|}{0.37} & \multicolumn{2}{|c|}{0.25} \\
\hline
\end{tabular}

Overall evaluated calibration and validation results indicated that the model is capable of simulating data correctly.

Period duration from sowing to anthesis and maturity for both sites showed significant differences between locations and sowing dates (Table 7). The longest duration of days from sowing to anthesis (282) was observed for sowing date 1 September in both locations during 2017-2018 growing season. Meanwhile, the shortest duration to anthesis (255) in Biržai was for sowing date 29 September in 2017-2018 season, but in Kaunas it reached anthesis 6 days faster (249) for same sowing date in 2018-2019 season. The longest period duration of days to maturity in Biržai and Kaunas for sowing date 1 September in 2016-2017 was 342 and 337 days, respectively. On the contrary, the shortest period duration of days to maturity was 306 in Biržai and 301 in Kaunas when wheat was sown 22 September in 2017-18 season. In general, intentionally delayed sowing time forced wheat to advance their anthesis $(r=-0.99, p<0.05)$ and maturity $(r=-0.98, p<0.05)$ dates. With each delayed week of sowing, anthesis date advances by 5.8 days and maturity date advances by 5.5 days.

Table 7. Observed winter wheat phenological dates (DOY) from sowing to anthesis and maturity with different sowing times in three growing seasons

\begin{tabular}{lccccccc}
\hline Location & Sowing date & \multicolumn{3}{c}{ Days to anthesis } & \multicolumn{3}{c}{ Days to maturity } \\
\hline \multirow{3}{*}{ Biržai } & $2016-2017$ & $2017-2018$ & $2018-2019$ & $2016-2017$ & $2017-2018$ & $2018-2019$ \\
& & 276 & 282 & 280 & 342 & 327 & 335 \\
& 1 September & 269 & 275 & 277 & 335 & 320 & 328 \\
& 8 September & 267 & 271 & 269 & 328 & 316 & 321 \\
& 15 September & 264 & 264 & 261 & 321 & 316 & 314 \\
Kaunas & 22 September & 257 & 255 & 258 & 314 & 311 & 313 \\
& 29 September & 280 & 282 & 270 & 337 & 322 & 330 \\
& 1 September & 272 & 268 & 265 & 330 & 315 & 323 \\
& 8 September & 264 & 265 & 259 & 323 & 308 & 316 \\
& 15 September & 261 & 260 & 254 & 316 & 306 & 309 \\
\hline
\end{tabular}

Observed temperature data (Table 1) shows that Biržai experimental site was significantly cooler than Kaunas, so wheat grown in the northern area had to grow to maturity for more days than those in the south. The temperature had a significant influence $(r=0.97, p<0.05)$ on plant development from sowing to anthesis and to maturity $(r=0.93 p<0.05)$. The same applies to precipitation effects on phenology, where there was a significant correlation between amount of rainfall and days to anthesis $(r=0.93, p<0.05)$, and $(r=0.91, p<0.05)$ days to maturity.

DSSAT model was used to simulate tiller number of winter wheat. Wheat sown on 1 September reaches highest number of tillers (1419 tillers $\mathrm{m}^{-2}$ ) in fall (Fig. 3). On later sowing dates before wintering wheat grew significantly less tillers. For example, when the sowing date was delayed by 3 weeks ( 15 September) the number of tillers was more than twice (643 tillers $\mathrm{m}^{-2}$ ) lower than in early September. Wheat sown on 29 September grew least number of tillers - 489 tillers $\mathrm{m}^{-2}$. Also, a significant negative correlation between delayed sowing date and tiller number in fall was noticed $(r=-0.98, p<0.05)$. 


\section{AGRICULTURAL AND FOOD SCIENCE}

M. Klepeckas et al. (2020) 29: 346-358

Comparing simulated results between sites there was found no significant differences of simulated tiller number between Kaunas and Biržai sites. In spring, when wheat completes tillering stage the highest number of tillers was simulated for sowing date 8 September, and it reached 2024 tillers per square meter at maturity. Meanwhile wheat sown on 1 September tended to grow less tillers (1977 tillers $\mathrm{m}^{-2}$ ) than wheat sown on 8 September and 15 September. Finally, lowest number of tillers was simulated for wheat sown on 29 September, they grew up almost twice less tillers (1287 tillers $\mathrm{m}^{-2}$ ) compared to ones sown on 8 September.

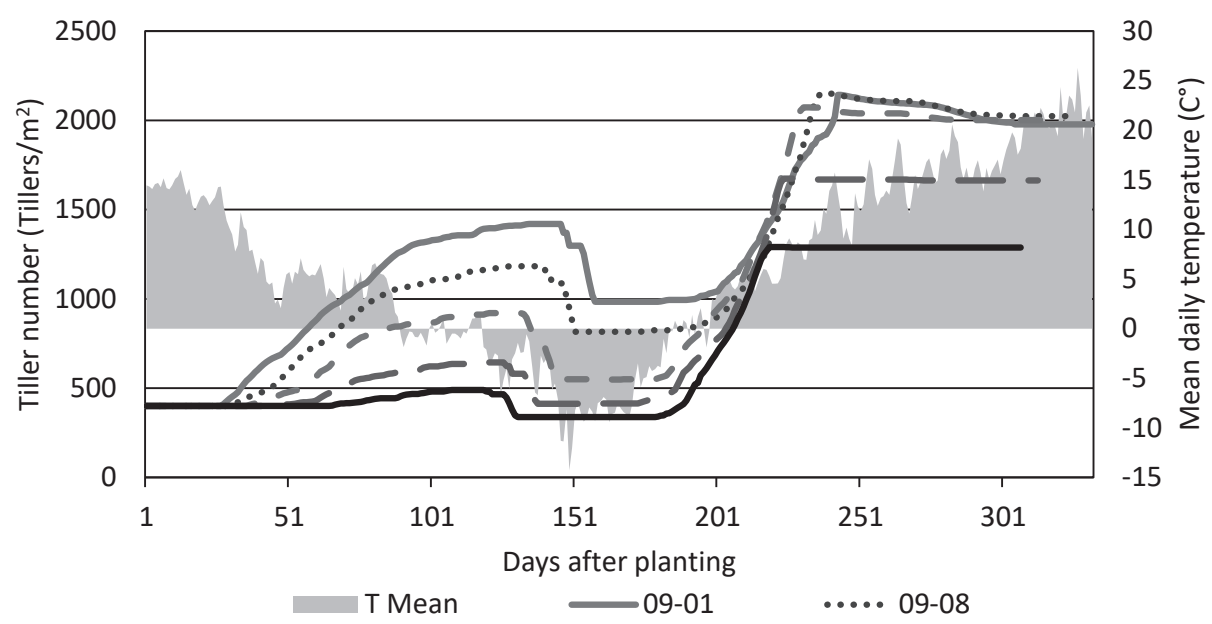

Fig. 3. Simulated tiller number (tillers $\mathrm{m}^{-2}$ ) at different sowing time, plotted with observed mean 3-year daily temperature during growth period

A strong negative correlation between the sowing time and the grain filling phase was found in simulated $(r=-0.97$, $p<0.05)$ and observed $(r=-0.96, p<0.05)$ data in both experiment locations (Fig. 4). The longest observed mean grain-filling period for wheat sown on 1 September was 55.8 days in Biržai and 55 days in Kaunas in three years of experiment. Sowing dates 22 September and 29 September distinguished for the shortest observed grain filling time (50.7, 50.1 days in Biržai and 50.3 days in Kaunas). Also, observed grain filling time showed strong correlation with observed vegetation period temperature $(r=0.96, p<0.05)$, precipitation $(r=0.8, p<0.05)$ and thermal time $(r=0.83, p<0.05)$.

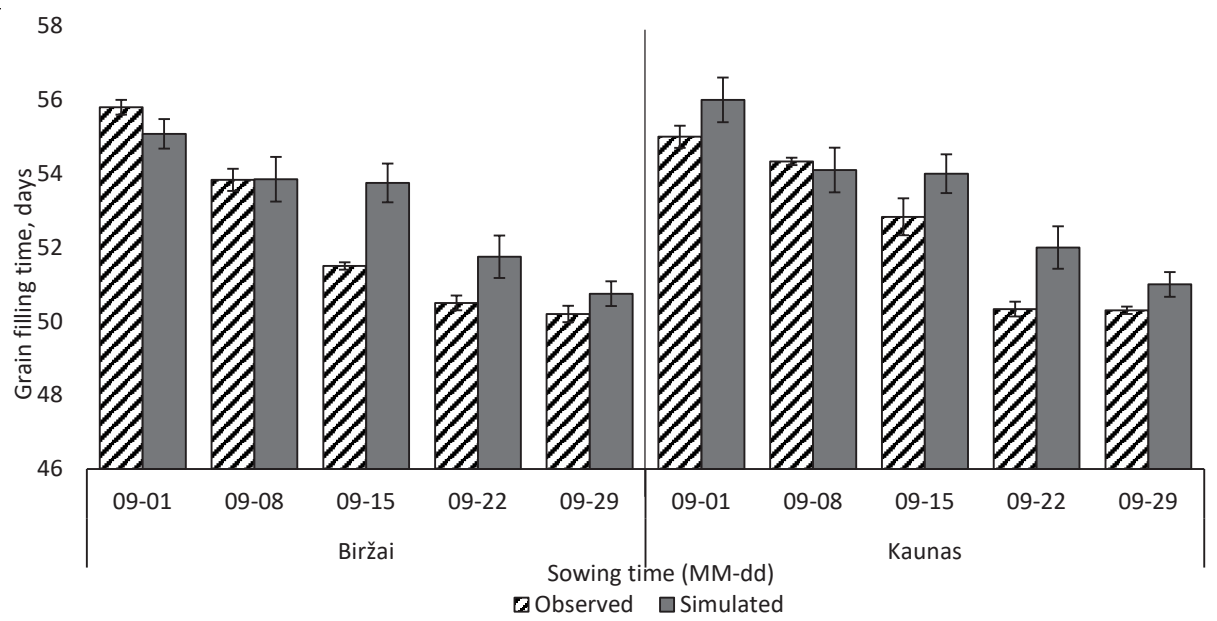

Fig. 4. Simulated and observed winter wheat grain filling phenological stage duration (days) at different sowing time

In most cases it is seen that model tends to overestimate grain filling time on average by 0.8 days $(p<0.05)$ as compared to observed data. Simulated results showed that in Biržai (1 September) grain filling period takes 55 days and in Kaunas - 56 days to complete this phase when wheat is sown in early September. With each delayed week grain filling time shortens by 1.25 days and compared to early sowing date (1 September) grain filling phase is shorter by 5 days when sowing occurred on 29 September. 


\section{AGRICULTURAL AND FOOD SCIENCE}

M. Klepeckas et al. (2020) 29: 346-358

Harvested yield results (Fig. 5) showed that when winter wheat is sown in mid-September (8 September and 15 September) in both locations grew the highest amounts of yield. At these sowing dates harvested yield was 7.51, 7.52 t ha-1 in Biržai and 8.58, 8.41 $\mathrm{t} \mathrm{ha}^{-1}$ in Kaunas respectively. When wheat was sown in the beginning of September (1 September) in Biržai yield was $6.5 \mathrm{t} \mathrm{ha}^{-1}$ and in Kaunas $7.2 \mathrm{t} \mathrm{ha}^{-1}$. Lowest quantities of wheat were harvested in late September (29 September) and yields were significantly lower in Biržai ( $\left.6 \mathrm{t} \mathrm{ha}^{-1}\right)$ and Kaunas $\left(6.8 \mathrm{t} \mathrm{ha}{ }^{-1}\right) \mathrm{com}^{-}$ pared to early sowing date.

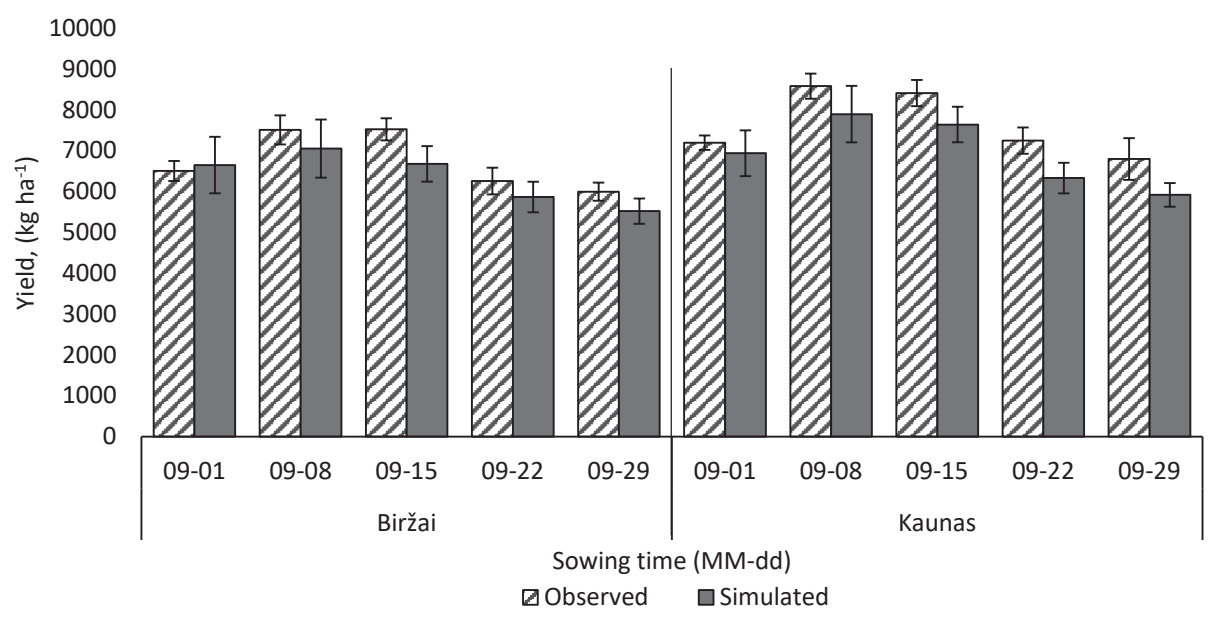

Fig. 5. Harvested and simulated yield (at maturity) at different sowing time

The highest simulated yield was recorded when wheat was sown on 8 and 15 September similarly to observed data. Lowest amount of simulated yield was $5.52 \mathrm{t} \mathrm{ha}^{-1}$ in Biržai and $5.92 \mathrm{t} \mathrm{ha}^{-1}$ in Kaunas when sowing time was on 29 September. Both locations - Kaunas and Biržai, had strong correlation between simulated and observed yield results $(r=0.99, p<0.05)$ and differences between them showed no significance. Overall, both simulated and observed yield results have a strong corelation with meteotological data $(p<0.05)$.

\section{Discussion}

Model calibration was performed using data from three-year experiment of different winter wheat sowing time results. Main genetic coefficient values of model were close to the recent author studies of winter wheat modeling shown in Table 3, except grain filling phase duration parameter (P5) where it reached $894.6^{\circ} \mathrm{C}$ and compared to other author findings it was slightly greater (Feng et al. 2015, Attia et al. 2016, Tang et al. 2018). On the other hand, our observed experimental data shows that grain filling thermal time requirement takes from 850 to $966^{\circ} \mathrm{C}$. The genetic coefficients used in the DSSAT model characterize winter wheat growth and development, these values can have differences due to many variables (as in field experiments) i.e. growing area, soil type, management practices (Dias and Lidon 2009, Dettori et al. 2011). Crop modeling can simulate crop phenology under specific conditions, but results can still be uncertain as results depend on simulation accuracy and precision calibration of the crop model (Liu et al. 2018b).

Crop phenology is instantly affected by crop management change (different cultivar or sowing date adjustment) (Xiao et al. 2013, Liu et al. 2018a). Result of this study showed that sowing time can have a strong impact on winter wheat phenology. When sowing time is delayed, anthesis $(r=-0.99)$ and maturity $(r=-0.98)$ phenological stages advances significantly. According to Ding et al. (2016), the overall growth period decreased by 4 days when sowing date postponed only by 5 days. However, adjusting sowing time can help to mitigate climate change effects on wheat growth and yield. For example, with delayed sowing time winter wheat can be presented to cooler temperatures during warm fall or winter and prevent their unexpected flourishing (Rezaei et al. 2015, Ding et al. 2016, Liu et al. 2016, 2018a). Here we demonstrate that intentionally delayed sowing time can advance anthesis and maturity phenological stages nearly 6 days with each delayed sowing week. As Xiao et al. (2013) noticed, that due to climate change sowing time gets delayed and because of that average anthesis, and maturity date has advanced by 1.1, 2.7, and 1.4 days per decade in the North China. They also noticed that wheat phenological development is significantly decelerated when an average temperature and thermal time significantly decreases during the winter wheat growing season. 


\section{AGRICULTURAL AND FOOD SCIENCE}

M. Klepeckas et al. (2020) 29: 346-358

One of the main things that independently changes together with delayed sowing date is mean vegetation period temperature and precipitation amount that plants get (Table 1). Average temperature of 2017-2018 season was significantly warmer in both locations with increased amount of rainfall compared to other two growing seasons. Mean amount of accumulated thermal time was greater by $110^{\circ} \mathrm{C}$ than in one year before and after, and this could have had a direct influence on wheat growth and phenology. Precipitation amounts for all sowing dates, during 2017-2018/2018-2019 seasons was higher in Kaunas than Biržai by 90 mm ( $p<0.05)$. And a downwards precipitation trend can be noticed when sowing dates are delayed, in both locations $(r=0,97 p<0.05)$ similarly to temperature. Other researchers (Sadras and Monzon 2006, Aslam et al. 2017) reported similar findings and concluded that wheat phenology has a strong correlation with sowing time, when different sowing dates have different mean vegetation period temperatures and precipitation amounts. When wheat is sown from 10 to 30 September, precipitation amounts decreased together with delayed sowing time (Ding et al. 2016). Sowing dates should be considered not only because farming practices changes, but it also can help to protect plants from negative effects of climate change (e.g. frosts or heat waves) (Wang et al. 2015). Temperature acclimatization of the wheat is linked to different functional capacities that regulate factors such as phenological growth, metabolic components, and redox balance (Hosseini et al. 2016). Same can be said considering thermal time - with delayed sowing date, thermal time lowered significantly. With every delayed week in sowing date mean vegetation period temperature dropped by $0.16^{\circ} \mathrm{C}$, and available GDD by $94.5^{\circ} \mathrm{C}$ respectively (Table 1). Other long-term study of winter wheat showed that when winter wheat growing season temperature increases by $0.2^{\circ} \mathrm{C}$, available GDD increases by $44.5^{\circ} \mathrm{C}$ (Ding et al. 2016).

Modeling results showed that with delayed sowing date the rate of tiller growth can be significantly reduced (Fig. 3). We found that winter wheat grew 232 (tillers $\mathrm{m}^{-2}$ ) less with each week of delayed sowing in fall before wintering. And this number can significantly affect yield as Tilley et al. (2019) concluded that tillers grown in fall can be responsible for more than $87 \%$ of yield than ones produced in spring. Scott et al. (2019) noticed that earlier sown wheat can develop more tillers. But when wheat accumulate over $1000^{\circ} \mathrm{C}$ of growing degree days in tillering stage - tiller number decreases significantly. And we approve with their findings, because in this study winter wheat sown in early September ( 1 September) accumulated over $1000^{\circ} \mathrm{C}$ of thermal time had less tillers at maturity than wheat sown in mid-September (8 September 2015) which accumulated less thermal time. According to model output data, plant development stops in fall when mean daily temperature reaches around $0{ }^{\circ} \mathrm{C}$ and continues in spring when temperature rises above $0{ }^{\circ} \mathrm{C}$. During winter, some tillers are lost due to low temperatures. Most of tillers were lost when wheat was sown on 1 September, they lost 385 tillers. When wheat was sown in late September (on 22 September and 29 September) (compared to earlier sowing dates) tiller losses were much smaller and consisted 231 and 143 respectively $(p<0.05)$. This could have happened because wheat sown later had less thermal time to develop in fall. On the other hand, excessively high tillering can negatively affect the final tiller number as this may result to increased density of shoots and their competition also, because light quality lowers and affects the dynamic of tillering. Therefore, a reduced growth rate during this development phase may induce further reduction of the crop's sink by reducing the post-anthesis capacity for grain filling and affecting the final yield amount (Sparkes et al. 2006, Lynch et al. 2017).

Some authors (Xiao et al. 2015, Attia et al. 2016, Ding et al. 2016) agree that through modified sowing time climatic condition for plants changes significantly, it can be especially noticed in grain filling stage. Observed and simulated results (Fig. 4) showed that due to delayed sowing time grain filling period duration shortens significantly up to 5 days. Calculated correlation between observed sowing time and grain filling period duration showed a negative correlation ( $r=-0.96, p<0.05$ ) when 1 week of delayed sowing time reduces grain filling time approximately 1.25 days. Many authors agree that grain filling stage is very sensitive to temperature changes (Dias and Lidon 2009, Wang et al. 2013, Ding et al. 2016, Yan et al. 2019). The investigated meteorological data showed that relationship between grain filling time and temperature has strongest correlation $(r=0.96)$. Moreover, temperature fluctuations during this period are likely to increase heterogeneity of grain size (Nuttall et al. 2017) and since the grain filling is final stage when caryopses develop, its duration can determine grain weight and yield (Yan et al. 2019). At the same time DSSAT Nwheat model successfully predicted grain filling period with $98 \%$ accuracy compared to observed data. Observed and modeled results show that wheat is more susceptible to temperature induced stress during grain filling stage than anthesis (Liu et al. 2016). It was noticed that grain filling duration has a relation to thermal time $(r=0.83)$ and this can be caused by a decrease in the availability of stored carbohydrate reserves in the wheat stem, as some studies have shown a decrease in stem dry mass weight from 1.0 to $3.5 \mathrm{t}$ ha (Asseng et al. 2017, Lynch et al. 2017).

Correctly selected sowing date can help not only maximize yields but also increase their quality parameters (Liu et al. 2016, Luo et al. 2018, Yan et al. 2019). Observed yield results (Fig. 5) showed that in both experiment 
locations the highest yield can be expected when winter wheat is sown in the middle of September (8 September 2015), when the average harvested yield was $7.52 \mathrm{tha}^{-1}$ in Biržai and $8.5 \mathrm{t} \mathrm{ha}^{-1}$ in Kaunas. Benefits of correctly chosen sowing date can help to achieve correct length grain yield formation phase, higher water-use efficiency and even increase machinery use efficiency (Pirttioja et al. 2015, Flohr et al. 2018, Yan et al. 2019). It was noted that, on average, one deliberately delayed sowing week in both experimental locations could result in $7.7 \%$ or $0.58 \mathrm{t} \mathrm{ha}^{-1}$ losses in the current climate. Meanwhile simulated results showed $6 \%$ lower losses $\left(0.55 \mathrm{t} \mathrm{ha} \mathrm{f}^{-1}\right)$. Such yield changes are highly related to vegetative period temperature $(r=-0.95, p<0.05)$. Luo et al. (2018) noticed that delayed sowing can reduce grain yield almost linearly even for simulated future climate scenarios. It is seen that model simulated yield in $92 \%$ accuracy with close relationship $(r=0.99, p<0.05)$ between field experiment results. In contrast, it can be seen that on average model tends to underestimate yield by $6 \%\left(0.4 \mathrm{t} \mathrm{ha}^{-1}\right)$ in Biržai and by $10 \%$ $\left(0.74 \mathrm{t} \mathrm{ha}^{-1}\right)$ in Kaunas when comparing observed and simulated results, but these differences were not significant.

But since it is very hard to predict future weather and in practice the decision must be done without knowledge about true weather for coming fall or winter. One of the main things can be done is to analyze weather and plant development trends from past. Based on these trends we can predict possible climate conditions, anticipate plant development, and plan crop management ahead. Correctly chosen sowing date could offset some of the negative effects of future climate change as simulated results predicted even greater yield reductions with each $1^{\circ} \mathrm{C}$ increase (Rezaei et al. 2015, Ding et al. 2016, Kassie et al. 2016, Liu et al. 2016, 2017).

\section{Conclusions}

The DSSAT Nwheat model was successfully calibrated for winter wheat growth in Lithuania based on observed phenological phases and yield data from three-year experiment. Calibrated parameters showed close agreement with observed data and model performed well on simulating winter wheat grain filling, tillering stages and yield data. Model simulations and observed field data showed that delayed sowing date can have a strong impact on winter wheat phenology, when one week of delayed sowing can advance anthesis and maturity nearly 6 days, grain filling stage can shorten by 1.25 days and yield can decrease from 7.7 to $6.0 \%$. Analyzed data shows that all changes in wheat growth are strongly related with growth conditions that changes due to delayed sowing-date. From obtained results we can conclude that the optimal sowing date for winter wheat in Lithuania is between 8 and 15 September, but warming climate can force farmers to adapt to other sowing dates. Model proves to be a reliable tool for anticipating and overcoming such potential issues, by using crop modeling software to correctly select the sowing date and cultivar can be a major component in optimizing yield quality, reducing costs and damages and achieving sustainable production in the near and far future.

\section{References}

Adhikari, P., Omani, N., Ale, S., DeLaune, P.B., Thorp, K.R., Barnes, E.M. \& Hoogenboom, G. 2017. Simulated Effects of Winter Wheat Cover Crop on Cotton Production Systems of the Texas Rolling Plains. Transactions of the ASABE 60: 2083-2096. https://doi.org/10.13031/trans.12272

Aslam, M.A., Ahmed, M., Stöckle, C.O., Higgins, S.S. \& Hayat, R. 2017. Can growing degree days and photoperiod predict spring wheat phenology? Frontiers in Environmental Science 5: 57. https://doi.org/10.3389/fenvs.2017.00057

Asseng, S., Kassie, B.T., Labra, M.H., Amador, C. \& Calderini, D.F., 2017. Simulating the impact of source-sink manipulations in wheat. Field Crops Research 202: 47-56. https://doi.org/10.1016/j.fcr.2016.04.031

Attia, A., Rajan, N., Xue, Q., Nair, S., Ibrahim, A. \& Hays, D. 2016. Application of DSSAT-CERES-Wheat Model to Simulate Winter Wheat Response to Irrigation Management in the Texas High Plains. Agricultural Water Management 165: 50-60. https://doi.org/10.1016/j.agwat.2015.11.002

Bukantis, A. 2001. Climatic fluctuations in Lithuania against a background of global warming. Acta Zoologica Lituanica 11: 113120. https://doi.org/10.1080/13921657.2001.10512366

Bukantis, A. \& Rimkus, E. 2005. Climate variability and change in Lithuania. Acta Zoologica Lituanica 15: 100-104. https://doi.org/10.1080/13921657.2005.10512382

Cauvain, S. 2012. Breadmaking: an overview. In: Breadmaking. Woodhead Publishing. p. 9-31. https://doi.org/10.1533/9780857095695.9

Cho, K., Falloon P., Gornall, J., Betts, R. \& Clark, R. 2012. Winter wheat yields in the UK: uncertainties in climate and management impacts. Climate Research 54: 49-68. https://doi.org/10.3354/cr01085

Dettori, M., Cesaraccio, C., Motroni, A., Spano, D. \& Duce, P. 2011. Using CERES-Wheat to simulate durum wheat production and phenology in Southern Sardinia, Italy. Field Crops Research 120: 179-188. https://doi.org/10.1016/j.fcr.2010.09.008

Dias, A.S., \& Lidon, F.C. 2009. Evaluation of grain filling rate and duration in bread and durum wheat, under heat stress after anthesis. Journal of Agronomy and Crop Science 195: 137-147. https://doi.org/10.1111/j.1439-037X.2008.00347.x 
Ding, D.Y., Feng, H., Zhao, Y., He, J.Q., Zou, Y.F., \& Jin, J.M. 2016. Modifying winter wheat sowing date as an adaptation to climate change on the Loess Plateau. Agronomy Journal 108: 53-63. https://doi.org/10.2134/agronj15.0262

Feledyn-Szewczyk, B., Jończyk, K. \& Stalenga, J. 2018. Assessment of the usefulness of new winter wheat varieties (Triticum aestivum L.) for cultivation in organic farming. Journal of Research and Applications in Agricultural Engineering 63: 43-49.

Feng, H., Li, Z., He, P., Jin, X., Yang, G., et al. 2015. Simulation of Winter Wheat Phenology in Beijing Area with DSSAT-CERES Model. In: 9th International Conference on Computer and Computing Technologies in Agriculture (CCTA), in September in Beijing, China. p. 259-268. https://doi.org/10.1007/978-3-319-48354-2_27

Flohr, B.M., Hunt, J.R., Kirkegaard, J.A., Evans, J.R., Trevaskis, B., Zwart, A. \& Rheinheimer, B. 2018. Fast winter wheat phenology can stabilise flowering date and maximise grain yield in semi-arid Mediterranean and temperate environments. Field Crops Research 223: 12-25. https://doi.org/10.1016/j.fcr.2018.03.021

Guarin, J.R., Kassie, B., Mashaheet, A.M., Burkey, K. \& Asseng, S. 2019. Modeling the effects of tropospheric ozone on wheat growth and yield. European Journal of Agronomy 105:13-23. https://doi.org/10.1016/j.eja.2019.02.004

He, L., Asseng, S., Zhao, G., Wu, D., Yang, X., Zhuang, W. \& Yu, Q. 2015. Impacts of recent climate warming, cultivar changes, and crop management on winter wheat phenology across the Loess Plateau of China. Agricultural and Forest Meteorology 200: 135143. https://doi.org/10.1016/j.agrformet.2014.09.011

Hilden, M., Lehtonen, H., Bärlund, I., Hakala, K., Kaukoranta, T. \& Tattari, S. 2005. The practice and process of adaptation in Finnish agriculture. FINADAPT Working Paper 5.

Hoogenboom, G., Porter, C.H., Shelia, V., Boote, K.J., Singh, U., White, J.W., Hunt, L.A., Ogoshi, R., Lizaso, J.I., Koo, J., Asseng, S., Singels, A., Moreno, L.P. \& Jones, J.W. 2019. Decision Support System for Agrotechnology Transfer (DSSAT) Version 4.7.5 (https:// DSSAT.net). DSSAT Foundation, Gainesville, Florida, USA.

Hosseini, M., Maali-Amiri, R., Mahfoozi, S., Fowler, D.B. \& Mohammadi, R. 2016. Developmental regulation of metabolites and low temperature tolerance in lines of crosses between spring and winter wheat. Acta Physiologiae Plantarum 38: 87. https://doi.org/10.1007/s11738-016-2103-0

Hu, X., Huang, Y., Sun, W. \& Yu, L. 2017. Shifts in cultivar and planting date have regulated rice growth duration under climate warming in China since the early 1980s. Agricultural and Forest Meteorology 247: 34-41. https://doi.org/10.1016/j.agrformet.2017.07.014

Hunt, L.A., Pararajasingham, S., Jones, J.W., Hoogenboom, G., Imamura, D.T. \& Ogoshi, R.M. 1993. GENCALC: Software to facilitate the use of crop models for analyzing field experiments. Agronomy Journal 85: 1090-1094.

https://doi.org/10.2134/agronj1993.00021962008500050025x

Jones, J.W., Hoogenboom, G., Porter, C.H., Boote, K.J., Batchelor, W.D., Hunt, L.A., Wilkens P.W., Singh, U., Gijsman, A.J. \& Ritchie, J.T. 2003. DSSAT Cropping System Model. European Journal of Agronomy 18: 235-265. https://doi.org/10.1016/S1161-0301(02)00107-7

Kassie, B.T., Asseng, S., Porter, C.H. \& Royce, F.S. 2016. Performance of DSSAT-Nwheat across a wide range of current and future growing conditions. European Journal of Agronomy 81: 27-36. https://doi.org/10.1016/j.eja.2016.08.012

Li, Z.T., Yang, J.Y., Drury, C.F. \& Hoogenboom, G. 2015. Evaluation of the DSSAT-CSM for simulating yield and soil organic C and N of a long-term maize and wheat rotation experiment in the Loess Plateau of Northwestern China. Agricultural Systems 135: 90104. https://doi.org/10.1016/j.agsy.2014.12.006

Liu, B., Asseng, S., Müller, C., Ewert, F., Elliott, J., Lobell, D.B. \& Rosenzweig, C. 2016. Similar estimates of temperature impacts on global wheat yield by three independent methods. Nature Climate Change 6: 1130. https://doi.org/10.1038/nclimate3115

Liu, H.L., Liu, H.B., Lei, Q.L., Zhai, L.M., Wang, H.Y., Zhang, J.Z. \& Liu, X.X. 2017. Using the DSSAT model to simulate wheat yield and soil organic carbon under a wheat-maize cropping system in the North China Plain. Journal of Integrative Agriculture 16: 23002307. https://doi.org/10.1016/S2095-3119(17)61678-2

Liu, Y., Chen, Q., Ge, Q., Dai, J. \& Dou, Y. 2018a. Effects of climate change and agronomic practice on changes in wheat phenology. Climatic Change 150: 273-287. https://doi.org/10.1007/s10584-018-2264-5

Liu, Y., Chen, Q., Ge, Q., Dai, J., Qin, Y., Dai, L. \& Chen, J. 2018b. Modelling the impacts of climate change and crop management on phenological trends of spring and winter wheat in China. Agricultural and Forest Meteorology 248: 518-526.

https://doi.org/10.1016/j.agrformet.2017.09.008

Luo, Q., O'Leary, G., Cleverly, J. \& Eamus, D. 2018. Effectiveness of time of sowing and cultivar choice for managing climate change: wheat crop phenology and water use efficiency. International Journal of Biometeorology 62: 1049-1061. https://doi.org/10.1007/s00484-018-1508-4

Lynch, J.P., Doyle, D., McAuley, S., McHardy, F., Danneels, Q., Black, L.C. \& Spink, J. 2017. The impact of variation in grain number and individual grain weight on winter wheat yield in the high yield potential environment of Ireland. European Journal of Agronomy 87: 40-49. https://doi.org/10.1016/j.eja.2017.05.001

Menzel, A., Sparks, T.H., Estrella, N., Koch, E., Aasa, A., Ahas, R. \& Chmielewski, F.M. 2006. European phenological response to climate change matches the warming pattern. Global Change Biology 12: 1969-1976. https://doi.org/10.1111/j.1365-2486.2006.01193.x

Nuttall, J.G., O'Leary, G.J., Panozzo, J.F., Walker, C.K., Barlow, K.M. \& Fitzgerald, G.J. 2017. Models of grain quality in wheat-A review. Field Crops Research 202: 136-145. https://doi.org/10.1016/j.fcr.2015.12.011

Phakamas, N., Jintrawet, A., Patanothai, A., Sringam, P. \& Hoogenboom, G. 2013. Estimation of solar radiation based on air temperature and application with the DSSAT v4. 5 peanut and rice simulation models in Thailand. Agricultural and Forest Meteorology 180: 182-193. https://doi.org/10.1016/j.agrformet.2013.06.015

Pirttioja, N., Carter, T.R., Fronzek, S., Bindi, M., Hoffmann, H., Palosuo, T. \& Asseng, S. 2015. Temperature and precipitation effects on wheat yield across a European transect: a crop model ensemble analysis using impact response surfaces. Climate Research 65: 87-105. https://doi.org/10.3354/cr01322 


\section{AGRICULTURAL AND FOOD SCIENCE}

M. Klepeckas et al. (2020) 29: 346-358

Porter, C., Jones, J.W. \& Braga, R. 2000. An approach for modular crop model development. International Consortium for Agricultural Systems Applications 2440: 13.

Rezaei, E.E., Siebert, S. \& Ewert, F. 2015. Intensity of heat stress in winter wheat-phenology compensates for the adverse effect of global warming. Environmental Research Letters 10: 024012. https://doi.org/10.1088/1748-9326/10/2/024012

Rimkus, E., Kažys, J., Junevičiūte, J. \& Stonevičius, E. 2007. Lietuvos klimato pokyčių XXI amžiuje prognozè. Geografija 43: $99-109$.

Rimkus, E., Kažys, J., Butkutè, S. \& Gečaitè, I. 2014. Snow cover variability in Lithuania over the last 50 years and its relationship with large-scale atmospheric circulation. Boreal Environment Research 19: 337-351.

Ruzgas, V., Liatukas, Ž., Razbadauskienè, K., Koppel, R. \& Brazauskas, G. 2017. The new winter wheat cultivars' Kena DS','Gaja DS','Sedula DS'and'Herkus DS' for increased yield stability. Zemdirbyste-Agriculture 104. https://doi.org/10.13080/z-a.2017.104.037

Sadras, V.O. \& Monzon, J.P. 2006. Modelled wheat phenology captures rising temperature trends: Shortened time to flowering and maturity in Australia and Argentina. Field Crops Research 99: 136-146. https://doi.org/10.1016/j.fcr.2006.04.003

Scott Tilley, M., Heiniger, R.W. \& Crozier, C.R. 2019. Measuring Tiller Development and Mortality in Winter Wheat under Field Conditions. Agrosystems, Geosciences \& Environment 2: 1-11. https://doi.org/10.2134/age2018.12.0066

Sparkes, D.L., Holme, S.J. \& Gaju, O. 2006. Does light quality initiate tiller death in wheat? European Journal of Agronomy 24: 212-217. https://doi.org/10.1016/j.eja.2005.08.003

Tang, X., Song, N., Chen, Z., Wang, J. \& He, J. 2018. Estimating the potential yield and ETc of winter wheat across Huang-Huai-Hai Plain in the future with the modified DSSAT model. Scientific Reports 8. https://doi.org/10.1038/s41598-018-32980-4

Thaler, S., Eitzinger, J., Trnka, M. \& Dubrovsky, M. 2012. Impacts of climate change and alternative adaptation options on winter wheat yield and water productivity in a dry climate in Central Europe. The Journal of Agricultural Science 150: 537-555. https://doi.org/10.1017/S0021859612000093

Tilley, M.S., Heiniger, R.W. \& Crozier, C.R. 2019. Tiller initiation and its effects on yield and yield components in winter wheat. Agronomy Journal 111: 1323-1332. https://doi.org/10.2134/agronj2018.07.0469

Wang, B., Li Liu, D., Asseng, S., Macadam, I. \& Yu, Q. 2015. Impact of climate change on wheat flowering time in eastern Australia. Agricultural and Forest Meteorology 209: 11-21. https://doi.org/10.1016/j.agrformet.2015.04.028

Wang, J., Wang, E., Feng, L., Yin, H. \& Yu, W. 2013. Phenological trends of winter wheat in response to varietal and temperature changes in the North China Plain. Field Crops Research 144: 135-144. https://doi.org/10.1016/j.fcr.2012.12.020

Wittich, K.-P. \& Liedtke, M. 2015. Shifts in plant phenology: a look at the sensitivity of seasonal phenophases to temperature in Germany. International Journal of Climatology 35: 3991-4000. https://doi.org/10.1002/joc.4262

Xiao, D., Moiwo, J.P., Tao, F., Yang, Y., Shen, Y., Xu, Q. \& Liu, F. 2015. Spatiotemporal variability of winter wheat phenology in response to weather and climate variability in China. Mitigation and Adaptation Strategies for Global Change 20: $1191-1202$. https://doi.org/10.1007/s11027-013-9531-6

Xiao, D., Tao, F., Liu, Y., Shi, W., Wang, M., Liu, F. \& Zhu, Z. 2013. Observed changes in winter wheat phenology in the North China Plain for 1981-2009. International Journal of Biometeorology 57: 275-285. https://doi.org/10.1007/s00484-012-0552-8

Yan, S., Wu, Y., Fan, J., Zhang, F., Qiang, S., Zheng, J. \& Zou, H. 2019. Effects of water and fertilizer management on grain filling characteristics, grain weight and productivity of drip-fertigated winter wheat. Agricultural Water Management 213: 983-995. https://doi.org/10.1016/j.agwat.2018.12.019

Yao, N., Zhou, Y., Song, L., Liu, J., Li, Y., Wu, S. \& He, J. 2015. Parameter estimation and verification of DSSAT-CERES-Wheat model for simulation of growth and development of winter wheat under water stresses at different growth stages. Transactions of the Chinese Society of Agricultural Engineering 31: 138-150.

www.fao.org

www.meteo.It 